\title{
Transforming Social Work Education in India: Integrating Human Rights
}

\author{
Vimla V. Nadkarni ${ }^{1} \cdot$ Roopashri Sinha ${ }^{2}$
}

Published online: 23 March 2016

(C) Springer International Publishing 2016

\begin{abstract}
India is one of the signatories to the UDHR. Its written constitution provides a unique combination of justiciable and non-justiciable rights. In India, the human rights movement and its intellectual discourse have been put to the test due to the specific complexities of the political processes in the country as well as due to the distinct historical, social, and cultural situations in Indian states. The residual traditional norms of caste, class and gender inequality, poverty, lack of education, and awareness are major hindrances in popularizing and internalizing human rights and making it into a mass movement. There is growing demand for social workers to adopt the human rights approach, particularly with increasing social and economic inequalities, poverty, religious and civil conflicts, disasters, and displacements. In this paper, the authors present a brief history of India's response to the human rights conventions and treaties and the current status of human rights practices. Social work education is a very important entry point for human rights practice and protection of the rights of the poor, marginalized, and the most disadvantaged people in the country. How Indian social work education has tailored its curricula, research, and field practice to embrace the human rights perspective is discussed and debated. While
\end{abstract}

Roopashri Sinha

roopashrisinha@gmail.com

Vimla V. Nadkarni

vimla1912@gmail.com; vimla@iassw-aiets.org

1 International Association of Schools of Social Work, School of Social Work, Tata Institute of Social Sciences, V.N. Purav Marg, Opposite Deonar Bus Depot, Post Box 8313, Mumbai 400 088, India

2 Shridev Sharvana Bldg. Room No. 102, Navghar Road, Lane No. 2, Mulund East, Mumbai 400081, India there are several challenges and differences in social work perspectives in the education of social workers in India, it is now well acknowledged that collective analysis and solidarity will facilitate the transformation of social work education in India into an effective discipline with a human rights perspective.

Keywords Indian social work education $\cdot$ Human rights perspective $\cdot$ Collective rights $\cdot$ Transformation $\cdot$ Human rights practice

\section{Introduction}

Social work and human rights are integrally related as both focus on inherent dignity of human beings and respect for their well-being through the protection of their rights whether as basic as shelter, food, clean water and sanitation, education, health and livelihood, or their political rights as citizens. Both the international organizations of social work namely the Indian Association of Schools of Social Work (IASSW) and International Federation of Social Workers (IFSW) have endorsed the significance of the Universal Declaration of Human Rights (UDHR) by acknowledging that social work is a profession and academic discipline that is based on a human rights perspective both in its theory and practice.

Today, there is growing demand for social workers to adopt the human rights approach, particularly with increasing social and economic inequalities, poverty, religious and civil conflicts, disasters, and displacements of large populations. The violation of human rights has been aggravated with the negative outcomes of globalization, privatization, and liberalization that focus more on expansion of trade and markets than enhancement of human well-being, particularly in countries that have been forced to reduce state investment in social 
sectors such as health, education, and the social services. Adoption of the human rights perspective in social work education to address these issues cannot be contested (Nadkarni 2014: xi). The human rights perspective is closely linked to social work, as both involve working with people who are disadvantaged, marginalized, vulnerable, and discriminated, whose rights are more susceptible and more difficult to shield. There is a need for passion to uphold equality and justice and anger against oppression and exploitation, to take up human rights work (Ife 2001).

\section{Defining Human Rights}

Human rights, in the broadest sense, are a set of beliefs about equal and inalienable rights of all humans essential for their well-being and for maintaining inherent human dignity. In the national context, human rights focus on the relationships between individuals, institutions, and corporations and society, specifically government, for ensuring respect to all humans. For purpose of application, we see human rights as a section of international law which includes the United Nations Charter, the 1948 Universal Declaration of Human Rights (UDHR), the International Covenant on Civil and Political Rights, and the International Covenant on Economic, Social, and Cultural Rights (1966). The enjoyment of civil and political rights and economic, social, and cultural rights are interconnected and interdependent (General Assembly resolution of 1950). The UDHR remains an inspiration to millions of people seeking self-determination and continues to stand as a "common standard of achievement for all peoples and nations" (UN 1948:1).

While it is true that the ideal of human rights in terms of values of dignity and equality of all members of the human race can be found in almost every culture and civilization, religion, and philosophical tradition, it is equally true that these have been disregarded by rulers and governments till forced to do otherwise by the citizenry or by international dynamics. It takes shape when people are constantly vigilant and courageous to stand for one's own rights and the rights of others (Levin 1981). Our experience of the development of human society has shown that the social, economic, and political progress helps to develop an appropriate base for the concept of human rights, which in turn plays a critical role in developing a human rights consciousness.

The vigor of the human rights environment in a country depends on the vision of the decision makers, strength of the society, depth of the law, vibrancy of the institutions, and use of discretionary powers by the state (Haragopal and Jagannatham 2009). The role of social workers is unquestionably to be found in creating this environment.

\section{Historical Moorings of Human Rights in India}

In India, there is an identifiable divide between efforts made on human rights issues in colonial India and a sovereign India. In the former, the British government on the behest of Indian social reformers and leaders made a handful of attempts to protect the vulnerable groups; In 1829 the practice of Sati was outlawed in British territories, and in 1929, the Child Marriage Restraint Act was passed, prohibiting marriage of minors under 14 years of age.

After independence in 1947, Indian leaders, greatly influenced by the UN Charter and the pledge to promote universal respect for human rights and fundamental freedoms, took on the task of writing the Indian Constitution. Despite the inherent asymmetries between post-colonial India's goals and the traditionally disparate, stratified civil society due to religion, race, language, tribe, caste, spatial location, and gender (Ray, 2003), India declared itself a secular, socialist, and democratic republic. Rule of law, universal adult franchise, division and balance of powers between legislature, executive and judiciary, and fundamental rights stated in the Indian Constitution became the chief tenets of Indian democracy as they had the potential to broaden the social base around citizens' rights.

India is one of the signatories to the UDHR. Its written constitution provides a unique combination of justiciable and non-justiciable rights. The first generation of human rights consisting of civil and political rights such as right to life, religion, expression, press, association, mobility, were included in the enforceable fundamental rights given in part III of the Indian Constitution. Most of the second generation of human rights, social, economic, and cultural including education, employment, livelihood, just and fair work conditions, food, housing, health, welfare, and social security measures for women, children, tribals, and minorities, were placed in the non-justiciable part IV of the constitution, in the directive principles of state policy. The third generation of collective human rights comprising of new concerns, like development, environment, refugees, displaced persons, and vulnerable sections of society that have been stated through many UN special covenants; for example, civil and political rights (1966), economic, social and cultural rights (1966), rights of development (1986), against torture (1984), against gender discrimination of women (1979), and rights of the child (1989), have also been respected by the respective governments as they have been signed and ratified by India. Paradoxically, free India had carried forward some of the institutions from the colonial rule, such as the civil and criminal procedure code, the penal code of 1860 , including the preventive detention acts and provisions. This set of citizens' rights together with the legal strictures (old and new) constitutes the present human rights discourse framework in India. 


\section{People's Struggles for Protection of Human Rights and State Response}

The history of people's efforts to ensure civil liberties goes back to 1936 when the All India Civil Liberties Union was founded by eminent freedom fighters of the time, and whose main goal was to establish the right to oppose the government. This union set a pathway for citizens' movements including investigations in cases of political imprisonments, police brutalities, and autocratic restrictions on freedoms and raising consciousness. In free India, the first Indian civil liberties organization, the Madras Civil Liberties Union was formed in 1948 , followed by a similar committee in West Bengal in the same year. This phase was primarily initiated by the Communist Party of India and it worked primarily for the comrades who came under state repression and persecution. Unfortunately the Party could not frame more comprehensive policies, nor broaden its base for the civil liberties movement (Chakrabarti 2011).

The formation of non-party human rights association began only in the 1970s with the setting up of the Association for the Protection of Democratic Rights (APDR) in West Bengal followed by the formation of Andhra Pradesh Civil Liberties Committee and other state level committees. The main demands of these groups at that time were related to ending all inhuman and undemocratic acts of the state, releasing all political prisoners, and the repeal of the draconian laws like Maintenance of Internal Security Act (Chakrabarti 2011). During the Emergency (1975-1976), when the executive had uncontrolled powers and the constitution was weakened, the People's Union for Civil Liberties and Democratic Rights (PUCLDR) was formed which had greater outreach in terms of protecting citizens rights. Around the same time, a call for Sampoorna Kraanti (Total revolution) was given by Jayprakash Narayan, which brought in the youth from all over India together to counter the offensive on people's rights and defeat the repressive government in the 1977 parliamentary elections.

Subsequently, a number of civil rights organizations were formed, at regional and national levels. These organizations found support from international human rights organizations such as Amnesty International, Human Rights Watch, UN's overseeing and monitoring Committees (e.g., The Convention on the Elimination of all Forms of Discrimination Against Women (CEDAW) and The Committee on the Rights of the Child (CRC), UNICEF). The steady build-up of institutions, processes, and academic interest over the years has transformed the more or less crises-linked, political party-based groups' struggle into an ongoing citizen movement.

In India, the human rights movement and its intellectual discourse have been put to test due to the specific complexities of the political processes in the country as well as due to the distinct historical, social, and cultural situations in Indian states. The residual traditional norms of caste, class and gender inequality, poverty, and lack of education and awareness are major hindrances in popularizing and internalizing human rights and making it into a mass movement. Brutal laws have taken away people's rights and there are many instances where the "rights-giving" constitution has not worked for the poor working masses. The right to livelihood, food, health, and nutrition remains a far dream, and they continue to undermine human rights efforts in India. Thus, there is a need to have individuals and organizations who can uphold human rights of those who are unable to do so.

Despite institutions like National Human Rights Commission (NHRC) ((http://nhrc.nic.in/)), and separate national commissions for protecting, preserving, and promoting the rights of women, children, minorities, and Scheduled Castes and Scheduled Tribes; these groups remain the most disadvantaged. Dalit and women have become more visible within the arena of electoral politics, than at the center stage of political democracy and human rights. As an activist revealed that Dalit women get left out even from welfare empowerment programs of the government and the struggle for equality is long and complex (Devika 2014). The basic rights of the indigenous people in India are often taken away by the state and non-state actors due to unregulated industrialization and growth of mineral-based industries in the tribal regions (Mehar 2009). Liberalization, privatization, and globalization in the agriculture sector has led to reduction of subsidies in agriculture, increased competitive market, and reduced social security, resulting in poverty, stress, and farmer suicides in the last decade (Moffatt et al. 2011).

Human Rights Watch has also pointed out that rising number of reported cases regarding violence against children, minorities, including lesbian, gay, bisexual, and transgender (LGBT), and people with disabilities, and HIV/AIDS and human rights activists have been neglected by government agencies meant to protect human rights (Human Rights Watch 2014). Sometimes, it is due to unclear political stand on the basic rights of a particular section of people. For example, in the case of child and forced marriages in India which is quite high despite many laws in the statute books. India's refusal to co-sponsor a United Nations Human Rights Council (UNHRC) resolution recognizing early and forced marriages of children as a human rights violation, probably reflects the theoretical conflict in the government's perspective on women's and children's human rights. While NGOs and child marriage prohibition officers try their best to prevent child marriages and use multi-pronged methods to solve the problem, their efforts would become more meaningful if the government was to recognize this problem as a denial of human rights and find solutions accordingly. 


\section{Human Rights and the Indian Legal Framework}

If one does a quick review of the Indian laws and the discretionary powers of the state, we find that some legislations have stayed since the mid-1950s and appear to be anomalies in the democratic system, namely, The Preventive Detention Act since the advent of independence, Punjab Security Act 1955, Assam Disturbed Areas Act 1955, and the Armed Forces (Assam and Manipur) Special Powers Act 1958. At present, there are about 20 to 30 repressive acts passed either at the central or the state levels (Haragopal and Jagannatham 2009) that keep the law-enforcing agencies above the law. The Unlawful Activities (Prevention) Amendment Act 2008, an amended version of the 1967 Act, was added to check terrorism but it gives uncontrolled power to the state. With recent spate of terrorist activities, the government's extra-judicial powers have increased. Critiques have pointed out that the law enforcing agencies apply the same methods as the terrorists, making the state more undemocratic in its functioning (Haragopal and Jagannatham 2009). More than 1600 complaints of extrajudicial killings were received by NHRC in a 5-year period (Human Rights Watch 2014). New onslaughts on human rights activists and organizations have come in the form of police actions against those who have expressed their views or have been critical of the government, by invoking the Information Technology Act and Foreign Contribution Regulation Act (FCRA).

In terms of concrete contributions, the Indian judicial system has played a critical role in defending human rights. The introduction of "public interest litigation" (PIL) in the early 1980s, generated a more active role for the judiciary in advancing human rights. A recent trend of the NHRC forging formal and informal links with the civil rights groups in the country is also heartening to the peoples' human rights movement. Legal reforms in crucial systems like prisons, elections, police, and judiciary have initiated the process of bringing in accountability and transparency in state run institutions. Reviews of repressive legislations are important in the process of decriminalization of institutions that fight for greater democracy and peoples' rights. The Right to Information Act, (RTI) 2005 that resulted from the tremendous pressure put by civil society organizations is a new landmark in the human rights movement in India as it has brought in transparency in governance and ensured citizens' right to know about the real time functioning of the governments and their agencies, to access data on government programs, and to know the rationale for decisions (Economic \& Political Weekly 2015). However, this too has suffered due to increasing attacks on RTI activists lately.

\section{Human Rights in Social Work Education}

Human rights has been a subject of critical enquiry in many social sciences as it has the potential to help students transcend social, cultural, and economic boundaries as well as make them aware of global interdependencies (Hornberg 2002). Human rights education overlaps with education for sustainable development. It can also provide a value framework for societies like India that are multicultural and multi-faith (Ian Lister, Cited In Ryszard Pachocinski 1993).

The integration of the human rights perspective and strategy in social work education has evolved more consciously over the past two decades, as debates about process, content, and how to evaluate implementation of human rights education itself, have become more realistic. The $\mathrm{UN}$ has proposed that human rights education (HRE) develops "a common responsibility to make human rights a reality in each community and in the society at large" (UN 2004, cited in Suárez 2007, p. 58).

Human rights can be taught through various models, three are more prominent than the others: (i) values and awareness model, (ii) the accountability model, and (iii) transformational model of education. In the values and awareness model, the main focus of HRE is to transmit basic knowledge of human rights issues, to encourage its integration into public values, and link up with fundamental democratic values and practice. The accountability model is primarily a legal/political approach, paying more attention to leadership and professionals' trainings and networking on human rights laws and codes, procedures for monitoring court cases, codes of ethics, dealing with the media, and public awareness. In the transformational model, HRE programming is geared towards empowering the individual and the communities to both recognize human rights abuses and to commit themselves to their prevention (Tibbitts 2002). While human rights can be taught through any of the three models or a combination of the three, Suarez cautions that it goes much beyond as it is about human lives (Suárez 2007). The UN posits a vision for all to follow leaving scope for the local academic communities to develop and construct an education model for human rights, suitable for the local conditions; one that takes into consideration the country's response to economic, social, and cultural globalization and policies imposed by lending agencies, governments, or power elites.

Under the aegis of United Nations Centre for Human Rights, International Association of Schools of Social Work (IASSW) and International Federation of Social Workers (IFSW) developed A Manual for Schools of Social Work and the Social Work Profession which was first published in 1992. The specific purpose was to add to the knowledge and understanding of all aspects of human rights and create international mechanisms to protect human rights. Its expressed aim was to help social workers utilize human rights concepts while working at individual, community, national, and international levels in all spheres of engagement. The manual could be adapted for continuing education of social workers, or infuse the human rights content with existing foundation or 
elective courses, or by initiating separate courses, thereby enriching it further (United Nations Centre for Human Rights 1994). The more recent manual prepared by the IFSW quotes a UN 1994 document: Article 1.4.3: "Human rights are inseparable from Social Work theory, values and ethics, and practice ... Advocacy of such rights must therefore be an integral part of Social Work, even if in countries living under authoritarian regimes such advocacy can have serious consequences for Social Work professionals" (United Nations 1994: 5 cited in IFSW European Region E.V. 2010: 6).

The embracing of the social work perspective is further articulated in the Global Definition of Social Work developed in 2014 (http://www.iassw-aiets.org/global-definition-ofsocial-work-review-of-the-global-definition/) as well as the Global Agenda for Social Work and Social Development, very seminal documents for guiding the social work fraternity in theory, practice and knowledge development (http://iassw-aiets.org; http://ifsw.org).

\section{The Indian Scenario of Social Work Education}

India with a rich legacy of charity and community work guided by religious texts, social and religious reformers, and Gandhian thought has a social work tradition that started much before formalized social work institutions were set up (Gore 1988). The history of the numerous struggles for civil and political rights, women's empowerment, and labor rights, includes contribution from trained social workers and "non-social work" activists. Both have nurtured each other in multiple ways.

Some of the social work literature in the 1960s reflects the relevance of human rights and its relationship with social work. Gore (1969) linked social work to the Universal Declaration of Human Rights as they both unequivocally recognize the worth and dignity of the person, irrespective of the individual's material or social condition, in his speech to the International Conference on Social Welfare in 1968. Phadke (1968) analyzed the structural issues that perpetuate poverty, child labor, and lack of a conducive environment for wellbeing, and advocated the importance of the social worker's role in human rights work. She observed that "The fulfillment of basic rights to food, clothing and shelter provide the essential groundwork for the exercise of other rights" (p. 22). She advocated that social workers should play a more dynamic role in addressing structural oppression and creating an egalitarian society for the "good of all" (Phadke 1968, p. 26). This was in keeping with the Gandhian concept of Sarvodaya.

Regardless of the insights provided by some of the veteran social workers and educators, social work in India has been slow in embracing the human rights perspective in practice. It is over the past two decades that formal social work education in India has evolved from the remedial, rehabilitative, western model of social work in mid-1940s to suit the requirement of an indigenous social work education catering to social development and change. The process mooted by the University Grants Commission (UGC) through the late 1980s and 1990s culminated in the UGC Model Curriculum of 2001 which was to be followed by the social work education programs in the country (Nadkarni, 2014). In 2004, representatives of schools of social work in India fleshed out minimum standards for social work education on behalf of the National Assessment and Accreditation Council (NAAC). They formulated the goals for social work education in the country as follows:

- Promoting the values of human dignity, human rights, democratic participation of people, peaceful, and collaborative social relationships.

- Challenging the unequal relationships and marginalization of people due to sex, age, ethnicity, caste, and creed.

- Democratizing the socio-economic and political systems by empowering people and building their capacity to bargain for basic rights and essential resources.

- Training students in culturally sensitive practice in relation to problem-solving skills, research, advocacy, disaster management, conflict resolution, policy formulation, and organizational management (NAAC 2005: 7-11).

This is in keeping with the Global Agenda for Social Work and Social Development (http://www.iassw-aiets.org/globalagenda/) that drew the attention of social workers on four major issues, namely social and economic inequalities, dignity of people, environmental sustainability, and importance of human relationships. The challenge is to translate this vision into reality.

Thus over the years, Indian social work education has proved its capacity to adapt to new demands and challenges, to indigenize and internationalize its curriculum in an almost simultaneous manner. Social work colleges in India are gradually incorporating the human rights perspective in their curricula and also pioneering programs and policy changes to protect the rights of the child, the girl child, women, and right to education, health, and livelihood (Nadkarni 2013, p. 4). These areas of work bring social work skills and human rights perspective quite actively into play and have been taken up without much hesitation by many NGOs and social workers. New issues that social workers are engaging with are rights of LGBT persons, People Living with HIV and AIDS, and the disabled. Social workers have been involved in human rights practice at the grassroots in collaboration with social, legal, community, development, and health activists. Strategies of advocacy and networking and campaigning on human rights issues have been adopted at various levels with varying degrees of success. Human rights-based social work, particularly when collective rights of communities are involved, demands redressal of structural blockages and elimination of root 
causes of social problems. This entails a deep commitment and passion for a cause, persistence, and patience, as well as optimism that social change is possible. Social workers turn to social activism to pursue these.

\section{Human Rights Practice at the Grassroots}

Social workers in India have played a lead in lobbying for land and forest rights for indigenous people, rights of people displaced by large dams, and many other issues. For example, the movements against large dams and for the rights of the displaced people as well as the movement for protecting the rights of Dalit women were initiated by social workers. Questioning the role of large dams mooted for "uplifting" the rural poor led to larger questions about skewed development and development for whom? This brought in support from civil society and community-based organization working on related issues like environment, forests, land, and water. The strategies included building evidence by conducting surveys with the help of well established social work institutions and other social research organizations and using this evidence for mobilizing international opinion and lobbying with the government for policy change (Essential Thinkers 2013). Similarly, the National Federation of Dalit Women aimed at developing Dalit women's leadership and strengthening the struggle against their oppression, by building solidarity with progressive secular mass movements (http:// karnataka.ngosindia.com/national-federation-of-dalitwomen-bangalore/).

Social workers have also played a significant role in the enactment of the Right to Information Act 2005 mentioned in the previous section. They participated with the group of activists who lobbied with the government to achieve transparency in the allocation of work and wages to the poor farmers in the Mahatma Gandhi National Rural Employment Guarantee Act (MNREGA) which led to the formation of the Right to Information Bill. The process is well documented by the Mazdoor Kisan Shakti Sangathan (MKSS) (Organization for the empowerment of workers and peasants, http://www. mkssindia.org/about-us/story-of-mkss/) a non-party people's movement which was formed in 1990 basically to ensure minimum wages to the rural labor affected by drought. The strategies adopted including evidence gathering, sharing the research findings with the people themselves, and positioning them to ask questions to the local administration through open public hearings (called jan sunwais) about the expenditure incurred and list of people who benefitted from the program (Roy Aruna and Dey Nikhil undated). There are also examples of Indian social workers playing a leadership role in international human rights organizations like Amnesty International.

Universities that have grown on the foundation of social work values continue to pursue the vision and mission of an egalitarian and socially just society. It is possible for the university to be a model for social transformation in many areas where there is great need for trained people for working on the rights of people living with mental illness, working with the elderly, with adolescent and youth, livelihoods and environmental sustainability, and so on. Social work educational institutions like the Tata Institute of Social Sciences and College of Social Work, Nirmala Niketan in Mumbai have demonstrated their support to the human rights perspective through teaching and practice. Field action is adopted as a strategy by faculty and students to identify an issue and demonstrate innovative interventions at the grassroots. These demonstrations of practice are researched and documented for their impact and translated into policy.

One of these practices has been clearly articulated by Rita Panicker, Director of a child rights NGO called Butterflies who analyzed the status of child rights in her article in the Indian Journal of Social Work (Panicker 1998). She noted the need for academicians to partner with NGOs in research and documentation, as well as the need for viewing child rights in a more holistic manner as children are part of the family and larger systems which needed social change. Since the last two decades of social work and civil society interventions, action on child rights is being achieved through child protection laws and child welfare commissions where social work has a major role to play in extending guidance and direction to the interventions. Professional social workers are active in these commissions and child welfare committees. Similarly, social workers working with non-government organizations have played major roles in marshaling and training rural poor communities to monitor the primary health care centers to ensure they receive quality health care which is integral to their right to health. Community-based monitoring (CBM) entails involving the people actively and encouraging them and their representatives, e.g., communitybased organizations, people's movements, voluntary organizations, and representatives of Panchayati Raj Institutions, to give feedback about the functioning of public health services and demand quality services. This process involves a three-way partnership between healthcare providers and managers (health system); the community, community-based organizations, NGOs and Panchayati Raj Institutions. The emphasis is on the "developmental spirit of 'fact-finding' and 'learning lessons for improvement' rather than 'fault finding"' (Garg and Laskar, 2010). This "allowing them to speak for themselves" approach reflects a change in client-provider relationship in professional social work making it more egalitarian.

The above examples reflect the scope of human rights practice at the field level by practitioners and the colleges/ schools/departments of social work and the need to research and document these experiences and build social work knowledge for use in social work education. However, it 
must be noted that human rights work involves challenging existing social structures that violate human rights of people, which raises some dilemmas while teaching and practicing the human rights perspective in social work. In the following and final section, the authors will present some of the opportunities and challenges.

\section{Opportunities and Challenges}

Social work has theory and practice more closely aligned to a human rights perspective than any of the other social sciences. Given the fact that social work trainees learn best from experiences from the field, the first step in training social workers in human rights, is making social work educational institutions live models for respecting and nurturing human rights. They have to evolve into institutions where learners do not feel disempowered. As some human rights education analysts have posed the question: "What do we tell our learners when they know about their human rights but cannot find meaningful ways to realize them" (Lohrenscheit 2002, p. 183).

If we take this framework for review and analysis of social work institutions one finds that quite a large number of India's social work colleges and departments have their foundation based on charity, liberal welfarism, and religious approaches. While they may not be anti-human rights, they do not promote the concept of human rights as strongly as those who have human rights values embedded in their vision-mission statements. The rights approach demands a paradigm shift from "needs fulfillment" to "ensuring rights", through a process of empowerment of people and accountability of authorities. Implementing human rights education in formal educational bodies can be a difficult task as it can be a critical pedagogy demanding comprehensive structural transformations in existing school settings. It can also put a strain on social work teachers, who are likely to lose their prestige due to the requirement of minimizing the unavoidable power structure in formal educational bodies (Suárez, 2007).

Social work training institutions may also be reluctant to introduce human rights in the curricula as it often means taking position against the policies of the government, especially if they are dependent on educational grants from the government. Social work training institutions face the dilemma of including human rights education in the curriculum without being condemned by their government for attempting to subvert its authority and of sowing seeds of discontent in the young minds. Another catch-22 question is how to pose the reality of the government's rationale for setting aside certain rights until the country's political economy is strong, while the students are discussing universality and inalienability of human rights? These questions become pertinent when the country's decision makers are unable to create an environment amenable to human rights.
A written human resource policy can rule out discriminatory practices and prejudices against students and staff belonging to the marginalized sections of society. In the Indian context this is especially relatable, as education has remained out of reach for the underprivileged especially the tribal, Muslims, and Dalit. The structure and organizational policies and procedures of the school must reflect its respect for human rights values, so that admissions and evaluations of students, hiring, firing, and promotions of faculty and other staff is conducted in a non-prejudiced and non-oppressive manner. This has also been clearly articulated in the IASSW document on Global Standards for Social Work Education and Training (http:// www.iassw-aiets.org/global-standards-for-social-workeducation-and-training/).

Social protection measures to ensure effective implementation of affirmative action and supportive mechanisms for students and staff of disadvantaged communities can go a long way in affirming human rights values as a key goal of the institution. For example, LGBT groups are coming out of the shadows and demanding entrance to colleges. Here a non-biased policy for admission of LGBT youth would confirm the institutions' respect for human rights of LGBTs. Moreover, incorporating the RTI document within the institution's system also ensures greater transparency. It also reflects the school's commitment to human rights and that it permeates its structure and inspires the learning process.

The second critical factor is the student-faculty relations that must be open and transparent, aiming at equality, mutual cooperation, minimizing hierarchy, upholding students' rights, and challenging all forms of oppression. HRE requires an interactive, participatory pedagogical approach as it is motivating, humanizing, and practical, with a potential for bringing about attitudinal and behavioral change (Tibbitts, 2002). Working in oppressive structures can make one prone to becoming part of that system, which can be remedied only if the problems are identified and dealt with on a regular basis. Using pedagogy that mentors students to work for social justice and human rights and upholding of students' rights becomes crucial. This requires a constant reflection and a readiness to solve the issues emanating from the hierarchical power of pedagogy in formal education systems. Therefore, social work colleges should ensure and promote democratic associations of staff and students, set up complaint redressal committees and sexual harassment committees, as these can facilitate communication and dialog between faculty and students.

Social workers are professionals who work towards values inherent in human rights and thus it is imperative that they learn to defend their own rights as well as fight against unfair and unjust systems that deny others their human rights. They have to be armed with the rights' perspective and skills vital to make human rights realizable in the communities they engage. Social work practice methods should be such that they stimulate a commitment to human rights. Indian social work 
education has benefited from sending their trainee social workers to the "rights-based" organizations and campaigns in the form of field visit, field work practicum and internship opportunities (Ejaz 1991, p. 301). A major problem here is the paucity of local field practicum sites as several local NGOs and government agencies do not share the human rights perspective.

As described above, some social work schools have found a way out to fill in the gap by initiating innovative field action projects. Several of them are able to upscale their work by registering as independent NGOs. Some of these projects also train students in research and advocacy.

With multiple diversities existing in social work college approaches, it is a daunting task to ensure a panIndian Social Work curriculum with a human rights perspective. Moreover there has been a ongoing tussle between traditional and critical social work regarding what should be given more prominence in social work curriculum. At a conference organized by Tata Institute of Social Sciences with its alumni in the early 1990s, one could see a clear divide of opinion about the future thrust of social work: conscientization of the marginalized and remedial orientation and clinical social work (Desai 1991 referenced in Nadkarni 2013). This dilemma is not one that will find an easy or quick resolution.

One of the blocks in integrating human rights completely in the curriculum of social work schools is the reluctance of faculty to venture into new areas of work. This is partly due to lack of ready resource materials for inclusion in the curriculum. Regional language books (original and translated) are hard to find in social work education. Many students including those who have passed out of English medium colleges are not fully equipped to understand nuances of this second language (Sajitha 2015). In a country as diverse as India with variations in terms of language, educational development, and diverse local human rights issues, the building of appropriate human rights resources for inclusion in social work schools spread over 29 states and seven union territories is a daunting task. Action skills for behavior change, attitudinal change, and empowerment skills need to be taught. Thus finding teachers who have both theoretical and practical expertise in human rights is essential. However, this remains another key concern, especially for colleges that are located far from major cities.

A major challenge that needs to be acknowledged is the tension between traditional social work, which tends to focus on needs-based assistance, and social work that focuses on ensuring human dignity and liberty by promoting human rights which has been intensified by processes of globalization. In this context, emphasis has been placed on the need to balance the perspective of needs-based assistance, which prevailed in the past and continues to prevail among policy makers, service providers, and many social workers, with the perspective of respecting and promoting human rights
(Hugman 2012 cited in Orit Nuttman-Shwartz and Ranz, 2015:2).

\section{Conclusion}

In order to make HRE a major field in academics and integrating it within a given educational programme the following activities are fundamental: (a) to develop a core body of knowledge through research, curriculum debates, documentation, and sharing of success stories and best practices; $b$ ) to identify clear goals for learners, develop a pedagogy built on sound knowledge of learner, learning theory, taking into account developmental theory; c) preparation of trainers by defining standards for theoretical and practical training, theoretical perspective, skills, and expertise of trainer (Tibbitts, 2002).

At one end, Indian social work education faces a massive task of ensuring minimum standards of quality of social work training in newly set up social work schools, and the other end, it continues to struggle for recognition by society and the state. Advocacy for the formation of a central council for professional social work that will monitor and regulate quality of social work education and practice and give appropriate direction for curricular development is likely to push the agenda for more recognition for social work. UGC and social work associations can help to rectify the current situation. They could also seek support from the agencies like IASSW's Committee on Human Rights which has been virtually active and can extend support in holding seminars and training in human rights. Indian social workers have started the process for setting up a strong association for social work education in December 2013 with funding support from IASSW. The association could also curb the problem of mushrooming of private social work colleges without adequate infrastructure for quality social work education.

The positive side is that it is now well-acknowledged by social work educators and curriculum experts that collective analysis and solidarity will facilitate the transformation of social work education in India into an effective discipline with a human rights perspective.

Acknowledgments The authors thank Ms. Purnima Upadhyay, Founder member KHOJ, Melghat, India, for her valuable inputs to this article.

\section{Compliance with Ethical Standards}

Conflict of Interest The authors declare that they have no competing interests.

Funding This study was self-funded. 


\section{References}

Chakrabarti, D. (2011). The human rights movement in India: in search of a realistic approach. Economic \& Political Weekly, 46(47), 33-40. Accessed on 20th Oct. 2015.

Desai, M. (1991). Issues concerning the setting up of social work specializations in India. International Social Work, 34, 83-95. Accessed on 20th Nov. 2015.

Devika, J. (2014). Becoming society, an interview with Seleena Prakkanam. Economic \& Political Weekly, xlLX(17). Accessed on 25th Oct. 2015.

Economic \& Political Weekly. (2015). Editorial, death by neglect. Economic \& Political Weekly, l(20). Accessed on 20th Oct. 2015.

Ejaz, F. K. (1991). Social work education in India: perceptions of social workers in Bombay. International Social Work, 34, 299-311. Accessed on 20th Nov. 2015.

Essential Thinkers (2013). The Story of Narmada Bachao Andolan, Retrieved from: https://essentialthinkers.wordpress.com/2013/10/ 13/the-story-of-narmada-bachao-andolan-human-rights/ Accessed on December 21, 2015.

Felisa Tibbitts. (2002), Understanding What We Do: Emerging Models for Human Rights Education, International Review of Education, 48, (3/4), Education and Human Rights (Jul., 2002), pp. 159-171 URL: http://www.jstor.org/stable/3445358. Accessed: 27-10-2015 05:45 UTC.

Garg, S., \& Laskar, A. R. (2010). Community-based monitoring: key to success of national health programs. Indian Journal of Community Medicine [serial online], 35, 214-6. Retrieved from: http://www. ijcm.org.in/text.asp?2010/35/2/214/66857. Accessed on 21 Dec. 2015.

Gore, M.S. (1969). 'Social Work and its Human Rights Aspects', in Social Welfare and Human Rights, Proceedings of the Fourteenth International Conference on Social Welfare. August 1968, Helsinki, Finland, pp. 56-68. New York: Columbia University Press for ICSW). Accessed on 20th Nov. 2015

Gore, M. S. (1988). Levels of social work provision in relation to needs in a developing society. The Indian Journal of Social Work, 49(4), 1-9. Accessed on 20th Nov. 2015.

Haragopal, G., \& Jagannatham, B. (2009). Terrorism and human rights: Indian experience with repressive laws. Economic \& Political Weekly, xliv(28). Accessed on 20th Oct. 2015.

Hornberg Sabine. (2002). Human Rights Education as an Integral Part of General Education, International Review of Education, 48(3/4), Education and Human Rights (Jul., 2002), pp. 187-198 Published by: Springer Stable URL: http://www.jstor.org/stable/3445360 Accessed: 27-10-2015 07:06 UTC.

Hugman, R. (2012). Human Rights and Social Justice. In M. Gray, J. Midgley, \& S. A. Webb (Eds.), The SAGE Handbook of International Social Work (pp. 372-85). London: Sage.

Human Rights Watch. (2014), World Report 2014: India. Retrieved from https://www.hrw.org/world-report/2014/country-chapters/india 2710-2015 05:15 UTC

Ife, J. (2001). Human rights and social work: Towards rights-based practice. In V. Nadkarni (Ed.), The Human Rights Perspective in Social Work with illustrations from Health Social Work. Cambridge, UK: Cambridge University Press.

International Association of Schools of Social Work (IASSW) Retrieved from: http://iassw-aiets.org.

International Federation of Social Workers (IFSW) Retrieved from: http:// ifsw.org.

International Federation of Social Workers, Standards In Social Work Practice meeting Human Rights, International Federation of Social Workers European Region E.V., 2010, pp. 12 . Retrieved from: http://ifsw.org/publications/standards-in-social-work-practicemeeting-human-rights/ on 19th November 2015.
Levin Leah. (1981). Human Rights: Questions \& Answers, National Book Trust, India in collaboration with UNESCO Publishing. Retrieved from http://www.arvindguptatoys.com/arvindgupta/ humanrightsnbt.pdf on 20th Nov. 2015.

Lohrenscheit Claudia, International Approaches in Human Rights Education, International Review of Education, 48(3/4), Education and Human Rights (Jul., 2002), pp. 173-185: http://www.jstor.org/ stable/3445359 Accessed: 27-10-2015 05:06 UTC.

Mehar, R. (2009). Globalization, displacement and the livelihood issues of tribal and agriculture dependent poor people: the case of mineralbased industries in India. Journal of Developing Societies, 25, 457480. Accessed on 29th Oct. 2015.

Moffatt, K., George, P., Alphonse, M., Kanitkar, A., Anand, V., \& Chamberlain, J. (2011). Community practice at a crossroads: the impact of global on the local in India. Community Development Journal, 46(1), 104-121. Accessed on 29th Oct. 2015.

Nadkarni, Vimla. (2013) Contextualizing Social Work Education: Lessons from the Indian Experience, (pp.1-16). In Zubai Meenai, Repositioning Social Work Education and Practice, Bloomsbury, New Delhi, 2013.

Nadkarni, Vimla. (2014). Foreword (pp.xi-viii), In Advancing Human Rights in Social Work Education, (edited by) Kathryn R, Libal, S. Megan Berthold, Rebecca L. Thomas, and Lynne M. Healy, Council on Social Work Education, Inc,, 2014).

National Assessment and Accreditation Council. (2005). Manual for SelfStudy of Social Work Institutions (pp. 7-11). Bangalore: NAAC. Accessed on 20th Nov. 2015.

National Federation of Dalit Women, Retrieved from: http://karnataka. ngosindia.com/national-federation-of-dalit-women-bangalore/ Accessed on December 17, 2015).

National Human Rights Commission, Retrieved from: http://nhrc.nic.in/ Accessed on October 10, 2015.

Orit Nuttman-Shwartz and Rebecca Ranz. (2015). Human rights discourse during a short-term field placement abroad: An experience of social work students from Israel and India, International Social Work 1-14, 2015. SAGE Journals. Retrieved from: http://isw.sagepub.com/content/early/2015/11/ 25/0020872815598568.full.pdf + html. Accessed on December $19,2015$.

Panicker, R.(1998). Children's rights: challenges and future thrust. Indian Journal of Social Work, 59(1), 276-290.

Phadke, S. (1968). Social welfare in the light of the enjoyment and exercise of human rights. The Indian Journal of Social Work, 29(1), 2126.

Ray, Aswini K. (2003). Human Rights Movement in India: A Historical Perspective, Economic and Political Weekly, August 9, 2003, pages 3409-3415. Accessed on 20th Oct. 2015.

Roy Aruna and Dey Nikhil,(undated) The Right to Information: Facilitating People's Participation and State Accountability. MKSS, Rajasthan. Retrieved from. http://www.10iacc.org/ download/workshops/cs54b.pdf. Accessed on 15-06-015.

Ryszard Pachocinski. (1993). Review of the Book, The Challenge of Human Rights Education by Hugh Starkey. International Review of Education. Vol. 39, No. 6, Education, Democracy, and Development (Nov., 1993), pp. 583-584 264 Pp). Retrieved from http://www.jstor.org/stable/3444986 Accessed on 27-10-2015 06:54 UTC.

Sajitha M.A. (2015). The relevance of four skill assessment in English language teaching. Retrieved from http://www.farookcollege.ac.in/ main/Downloads/mrp_sajitha_2014.pdf. Accessed on 29th Nov. 2015.

Suárez, D. (2007). Education professionals and the construction of human rights education. Comparative Education Review, 51(1), 48-70. Retrieved fromhttp://www.jstor.org/stable/10.1086/508638. Accessed on 27/10/2015 03:40 
United Nations. (1948). Universal Declaration of Human Rights, Retrieved from http:/www.ohchr.org/EN/UDHR/Documents/ UDHR Translations/eng.pdf. Accessed on 20th Oct. 2015.

UN (Centre for Human Rights) (1994). Human Rights and Social Work. Geneva: UN in collaboration with IFSW and IASSW http://cdn.ifsw. org/assets/Standards_meeting_Human_Rights-_Final_Report_pdf
United Nations Centre for Human Rights, Human Rights and Social Work: A Manual for Schools of Social Work and the Social Work Profession, Geneva, 1994. Retrieved from http://www.ohchr.org/ Documents/Publications/training1en.pdf. Accessed on 20th Nov. 2015. 